\title{
Cost-benefit indexes of deception in nonviolent crime
}

\author{
JOAN S. LOCKARD, BARBARA C. KIRKEVOLD, and DOUGLAS F. KALK \\ University of Washington, Seattle, Washington 98195
}

\begin{abstract}
Data on federal crimes for the years 1976-1977 are examined for the categories of fraud, embezzlement, and forgery-counterfeiting as compared with those of stolen property. A frequency analysis of the number of arrests by category of crime is conducted, and the numbers are subdivided by age and sex of perpetrator. The findings support the hypothesis that the cost-to-benefit indexes of crimes involving interpersonal deception are considerably lower than other nonviolent crimes of monetary gain. It is suggested that, as in many other social animals, human deception may be adaptive.
\end{abstract}

Many animal species have evolved a form of deception that is advantageous to their survival. For example, carnivores can be deceived by prey that pretend to be dead. Whereas an aversion to eating carrion inundated with microorganisms that produce toxic by-products is adaptive, this aversion is exploited by certain animals (e.g., some spiders, snakes, insects, and mammals) that fake death when approached by a predator.

Other animals (e.g., wasps, bees, and rattlesnakes) protected by possessing toxins through sting, bites, or sprays, on the contrary, behave in conspicuous ways and may be brightly colored or emit a warning noise before they strike. In this way, the prey do not have to be attacked in order to repel their enemies. Moreover, many nonnoxious species manage through mimicry of these animals to survive to reproduce others of their kind.

Deception is prevalent not only among members of different species, but also among animals of the same species. For example, cuckoldry in langur monkeys has been reported (Hrdy, 1977). Males of certain species of flies (Kessel, 1955) simulate a food package during courtship by offering the females empty silken bags. In some fish (Assem, 1967), a nonresident male gains access to a nest defended by a resident male by mimicking the behavior of a receptive female and releases his sperm in an attempt to fertilize some of the eggs.

Man, therefore, is not the only animal that "lies" to members of its own species. Wallace (1973) proposed a model of human deceit in which his basic assumption was that an accurate appraisal of one's environment is essential for high fitness. He hypothesized that an individual might increase his own relative fitness by causing a second individual to misinterpret the environment: "Thus, if two individuals are searching for food that is scarcely sufficient to support one of them alone, either one might raise his own fitness by convincing the other to search in barren places" (1973, p. 2). Wallace also

This research was supported by a grant from the Harry Frank Guggenheim Foundation. intimated that the deceiver would achieve a greater increment in his genetic contribution to the next generation (inclusive fitness; see Hamilton, 1964) if the deceived were nonrelatives with whom fewer genes are held in common. He further theorized that the ease of deception would be a function of the relative frequency of individuals in a population perpetrating the deception and of the ability of other individuals in the population to detect the deception, until a point is reached at which either (1) a stable ratio of deceivers to potential recipients prevails (i.e., an evolutionary stable strategy; see Maynard-Smith, 1976) or (2) it is no longer advantageous to continue the deception since those being deceived have, in turn, evolved to better detect (or learned to detect more quickly) attempted ploys. Wallace finally suggested that an individual who relies on lies for his survival should use large ones, since a big lie is not necessarily more difficult to contrive than a small one. For instance, how much more probable is the advantage of the deceit transmitted by a moth with eye spots if it conveys the message "Beware of the owl!" rather than "I'm not the moth you think I am."

In essence, Wallace (1973) proposed that misinforming another individual may well be adaptive when: (1) vital resources are in demand (i.e., competition is high), (2) the recipients are nonrelatives, (3) the deceivers are few and/or the ability to detect them is slight, and (4) the lie is a big one. Otte (1975) has tempered such speculation by indicating that the lie, to be effective, must not exceed the degree of gullibility of the receiver and that deceit among kin may in fact occur, is not always disadvantageous, and depends on the degree of relatedness, the resources available, and the current need to maintain cooperative alliances. With these ideas and qualifiers in mind, the intent of the present paper is to evaluate their merit as applied to crimes of interpersonal deception. Relevant data on nonviolent federal crimes for the years 1976-1977 are examined. The specific hypothesis being considered is that the risk of arrest and subsequent punishment of crimes such as fraud is appre- 
ciably lower than for crimes of stolen property, whereas the monetary returns from the former are greater than those from the latter. It is also proposed that the age and sex distributions of perpetrators are significantly different in the categories of interpersonal deception, compared with those of stolen property (for sex differences in crime more generally, see, e.g., Adler, 1975).

\section{METHOD}

\section{Definitions of Crime Categories}

For purposes of clarity of discussion, the four categories of nonviolent crime of focal interest are briefly defined (Webster, 1978). Fraud: Fraudulent conversion and obtaining money or property by false pretenses. Included are larceny by bailee and bad checks, except forgeries and counterfeiting. Embezzlement: Misappropriation or misapplication of money or property entrusted to one's care, custody, or control. Forgery and counterfeiting: Making, altering, uttering, or possessing, with intent to defraud, anything false that is made to appear true. Attempts are included. Stolen property: Buying, receiving, and possessing stolen property, including attempts.

\section{Data Analysis}

Some of the data on fraud, embezzlement, forgerycounterfeiting, and stolen property for the years 1976-1977, as collated by the U.S. Department of Justice (1978), the FBI (Webster, 1978), and the House of Representatives, 95th Congress (1978), were subjected to chi-square analyses. Observed and expected frequencies were compared for each crime in terms of sex and age (10-year blocks) of those arrested. Chisquare statistics were also conducted on the frequency of these crimes with respect to population density, as defined by the terms urban, suburban, and rural, and in terms of the number of arrests of males and females under and over the age of 18 years.

For the statistically sophisticated, it is important to note that the number of individuals per age-sex category that were not arrested is so large that their usual inclusion in the chi-square analyses would have merely inflated the values, and therefore, they were omitted.

\section{RESULTS}

As shown in Table 1, the actual number of arrests for forgery-counterfeiting, fraud, embezzlement, and stolen property were very significantly different for males and females of different ages $\left[\chi^{2}(33)=69,088.50\right.$, $\mathrm{p}<.0001$ ]. If only age is considered by type of crime, as in Table 2 , the differences in frequency are also very striking $\left[\chi^{2}(15)=52,788.36, p<.0001\right]$. If one compares only the sex of the offender with type of crime, as shown in Table 3, the differences in number of arrests are again highly significant $\left[\chi^{2}(3)=20,108.53\right.$, $p<.0001$ ]. If the large matrix of category of crime by sex and age (Table 1) is analyzed even more closely by all meaningful combinations of a 2 by 2 chi-square table (not shown), certain specific differences in number of arrests, and therefore in frequency of the crimes, become explicit. For instance, in crimes of deception (fraud, embezzlement, forgery-counterfeiting), the ratio of male to female offenders is $2: 1$, in contrast to crimes of stolen property, in which the ratio is $9: 1$ [e.g., fraud vs. stolen property: $\left.\chi^{2}(1)=20,163.61, p<.0001\right]$. Similarly, if one looks at the frequency of arrests by age of offender, crimes of deception peak between the ages of 20 and 29 years, whereas those of stolen property peak between the ages of 10 and 19 years [e.g., fraud vs. stolen property: $\left.\chi^{2}(1)=31,583.44, p<.0001\right]$. Moreover, whereas the differences in relative frequency among fraud, embezzlement, and forgery-counterfeiting are nonsignificant after the age of 39 years, the differences in relative frequency between crimes of deception and stolen property continue to be statistically different throughout the age range [e.g., fraud vs. stolen property for ages 50-59 years vs. greater than 60 years: $\left.\chi^{2}(1)=18.01, p<.001\right]$.

Table 1

Crime Data Analysis: Crime by Age by Sex

\begin{tabular}{|c|c|c|c|c|c|c|c|c|c|c|c|c|c|}
\hline \multirow{3}{*}{$\begin{array}{c}\text { Frequency } \\
\text { of Arrest }\end{array}$} & \multicolumn{12}{|c|}{ Age Group (in Years) } & \multirow[b]{3}{*}{ Total } \\
\hline & \multicolumn{2}{|c|}{$10-19$} & \multicolumn{2}{|c|}{$20-29$} & \multicolumn{2}{|c|}{$30-39$} & \multicolumn{2}{|c|}{$40-49$} & \multicolumn{2}{|c|}{$50-59$} & \multicolumn{2}{|c|}{60 and Older } & \\
\hline & Male & Female & Male & Female & Male & Female & Male & Female & Male & Female & Male & Female & \\
\hline & \multicolumn{13}{|c|}{ Forgery and Counterfeiting } \\
\hline \multirow[t]{2}{*}{$\begin{array}{l}\text { Empirical } \\
\text { Expected }\end{array}$} & $\begin{array}{r}9563 \\
10230\end{array}$ & $\begin{array}{l}4020 \\
2501\end{array}$ & $\begin{array}{l}20252 \\
18085\end{array}$ & $\begin{array}{l}8515 \\
7422\end{array}$ & $\begin{array}{l}6120 \\
7416\end{array}$ & $\begin{array}{l}2573 \\
3395\end{array}$ & $\begin{array}{l}2316 \\
3128\end{array}$ & $\begin{array}{r}974 \\
1447\end{array}$ & $\begin{array}{r}810 \\
1161\end{array}$ & $\begin{array}{l}341 \\
520\end{array}$ & $\begin{array}{l}198 \\
322\end{array}$ & $\begin{array}{r}83 \\
138\end{array}$ & 55765 \\
\hline & \multicolumn{13}{|c|}{ Fraud } \\
\hline \multirow[t]{2}{*}{$\begin{array}{l}\text { Empirical } \\
\text { Expected }\end{array}$} & $\begin{array}{r}9243 \\
29599\end{array}$ & $\begin{array}{l}5336 \\
7237\end{array}$ & $\begin{array}{l}50205 \\
52329\end{array}$ & $\begin{array}{l}28982 \\
21474\end{array}$ & $\begin{array}{l}26288 \\
21457\end{array}$ & $\begin{array}{r}15176 \\
9822\end{array}$ & $\begin{array}{r}11445 \\
9052\end{array}$ & $\begin{array}{l}6607 \\
4186\end{array}$ & $\begin{array}{l}4042 \\
3360\end{array}$ & $\begin{array}{l}2334 \\
1505\end{array}$ & $\begin{array}{r}1073 \\
930\end{array}$ & $\begin{array}{l}620 \\
400\end{array}$ & 161351 \\
\hline & \multicolumn{13}{|c|}{ Embezzlement } \\
\hline \multirow[t]{2}{*}{ Expected } & $\begin{array}{r}764 \\
1507\end{array}$ & $\begin{array}{l}344 \\
368\end{array}$ & $\begin{array}{l}2808 \\
2664\end{array}$ & $\begin{array}{l}1261 \\
1093\end{array}$ & $\begin{array}{l}1265 \\
1092\end{array}$ & $\begin{array}{l}569 \\
500\end{array}$ & $\begin{array}{l}538 \\
461\end{array}$ & $\begin{array}{l}241 \\
213\end{array}$ & $\begin{array}{l}243 \\
171\end{array}$ & $\begin{array}{r}109 \\
77\end{array}$ & $\begin{array}{l}50 \\
47\end{array}$ & $\begin{array}{l}23 \\
20\end{array}$ & 8215 \\
\hline & \multicolumn{13}{|c|}{ Stolen Property } \\
\hline $\begin{array}{l}\text { Empirical } \\
\text { Expected }\end{array}$ & $\begin{array}{l}38648 \\
16882\end{array}$ & $\begin{array}{l}4534 \\
4128\end{array}$ & $\begin{array}{l}29659 \\
29846\end{array}$ & $\begin{array}{r}3479 \\
12248\end{array}$ & $\begin{array}{r}8530 \\
12238\end{array}$ & $\begin{array}{l}1001 \\
5602\end{array}$ & $\begin{array}{l}3505 \\
5163\end{array}$ & $\begin{array}{r}411 \\
2387\end{array}$ & $\begin{array}{l}1513 \\
1916\end{array}$ & $\begin{array}{l}177 \\
859\end{array}$ & $\begin{array}{l}509 \\
531\end{array}$ & $\begin{array}{r}60 \\
228\end{array}$ & 92026 \\
\hline & \multicolumn{13}{|c|}{ Overall $\left[x^{2}(33)=69,088.497\right]$} \\
\hline Total & 58218 & 14234 & 102924 & 42237 & 42203 & 19319 & 17804 & 8233 & 6608 & 2961 & 1830 & 786 & 317357 \\
\hline
\end{tabular}

Note-The empirical frequencies of arrest for females of different ages are statistically estimated and are not absolute frequencies. The empirical frequencies of arrest for males of different ages and the totals for both males and females are absolute frequencies. 
Table 2

Crime Data Analysis: Crime by Age

\begin{tabular}{|c|c|c|c|c|c|c|c|c|}
\hline & \multirow{2}{*}{$\begin{array}{c}\text { Frequency } \\
\text { of Arrest }\end{array}$} & \multicolumn{6}{|c|}{ Age Group (in Years) } & \multirow[b]{2}{*}{ Total } \\
\hline & & $10-19$ & $20-29$ & $30-39$ & $40-49$ & $50-59$ & 60 and Older & \\
\hline Forgery/Counterfeiting & Empirical & 13583 & 28767 & 8693 & 3290 & 1151 & 281 & 55765 \\
\hline Fraud & $\begin{array}{l}\text { Empirical } \\
\text { Expected }\end{array}$ & $\begin{array}{l}14579 \\
36836\end{array}$ & $\begin{array}{l}79187 \\
73803\end{array}$ & $\begin{array}{l}41464 \\
31279\end{array}$ & $\begin{array}{l}18052 \\
13238\end{array}$ & $\begin{array}{l}6376 \\
4865\end{array}$ & $\begin{array}{l}1693 \\
1330\end{array}$ & 161351 \\
\hline Embezzlement & $\begin{array}{l}\text { Empirical } \\
\text { Expected }\end{array}$ & $\begin{array}{l}1108 \\
1875\end{array}$ & $\begin{array}{l}4069 \\
3758\end{array}$ & $\begin{array}{l}1834 \\
1593\end{array}$ & $\begin{array}{l}779 \\
674\end{array}$ & $\begin{array}{l}352 \\
248\end{array}$ & $\begin{array}{l}73 \\
68\end{array}$ & 8215 \\
\hline Stolen Property & $\begin{array}{l}\text { Empirical } \\
\text { Expected }\end{array}$ & $\begin{array}{l}43182 \\
21009\end{array}$ & $\begin{array}{l}33138 \\
42093\end{array}$ & $\begin{array}{r}9531 \\
17840\end{array}$ & $\begin{array}{l}3916 \\
7550\end{array}$ & $\begin{array}{l}1690 \\
2775\end{array}$ & $\begin{array}{l}569 \\
759\end{array}$ & 92026 \\
\hline Overall & Total & 72452 & 145161 & 61522 & 26037 & 9569 & 2616 & 317357 \\
\hline
\end{tabular}

Note $-\chi^{2}(15)=52,788.356$.

When the frequency of arrests of these crimes is examined with respect to locale (urban, suburban, or rural) in which the crime occurred, as shown in Table 4, several interesting differences also emerge. Whereas the absolute frequency of arrests is greatest in urban areas for both crimes of deception and stolen property, this is not the case when relative frequencies are considered. For instance, the observed frequencies of arrests for crimes of deception are significantly lower than the expected frequencies in suburban areas, whereas the reverse is true for crimes of stolen property $\left[\chi^{2}(6)=\right.$ $13,037.46, p<.0001]$. In contrast, for rural areas, only in the case of fraud is the actual frequency of arrests in excess of the predicted frequency; for forgerycounterfeiting or embezzlement, the empirical frequencies in rural areas are considerably lower than the predicted frequencies. All of these differences in frequency of arrest are particularly accentuated for adult males older than 18 years of age $\left[\chi^{2}(6)=6,768.77\right.$, $\mathrm{p}<.0001]$, but they are also characteristic of female adults $\left[\chi^{2}(6)=2,562.19, p<.0001\right]$ and of juveniles (less than 18 years of age) of both sexes [males: $\chi^{2}(6)=$ $587.65, \mathrm{p}<.0001$; females: $\left.\chi^{2}(6)=100.04, \mathrm{p}<.001\right]$.

\section{Costs and Benefits}

As shown in Table 5, the frequency of arrests for fraud is considerably greater than that for stolen property, forgery-counterfeiting, and especially embezzlement. Over 160,000 arrests for federal fraud charges occurred in 1976, compared with slightly over 92,000 for stolen property and a little more than 8,000 for embezzlement. However, the risk of indictment compared with the number of arrests is very low for fraud, with forgery-counterfeiting and stolen property in between and embezzlement highest. For instance, the ratio of indictments to arrests is 1 in 28 for fraud and 1 in 4 for embezzlement. Nevertheless, in all three crimes involving deception (particularly fraud and embezzlement), the average penalty in terms of months of imprisonment is considerably less than for crimes of stolen property. Whereas there is appreciable variability within crime categories themselves, it is still striking that the average sentence served for crimes of fraud and embezzlement is less than 20 months, slightly over 32 months for forgery-counterfeiting, and over 37 months for stolen property. In this regard, it is particularly interesting to note that the potential monetary value that could be realized from each crime is inversely

Table 3

Crime Data Analysis: Crime by Sex

\begin{tabular}{lcrrr}
\hline & $\begin{array}{c}\text { Frequency } \\
\text { of Arrest }\end{array}$ & \multicolumn{1}{c}{ Male } & Female & Total \\
\hline \multirow{2}{*}{ Forgery/Counterfeiting } & Empirical & 39255 & 16536 & 55791 \\
& Expected & 40365 & 15426 & \\
Fraud & Empirical & 102394 & 59035 & 161429 \\
& Expected & 116794 & 44635 & \\
Embezzlement & Empirical & 5670 & 2548 & 8218 \\
Stolen Property & Expected & 5946 & 2272 & \\
& Empirical & 82388 & 9667 & 92055 \\
Overall & Expected & 66602 & 25453 & \\
\hline
\end{tabular}

Note $-\chi^{2}(3)=20,108.532$.

Table 4

Crime Data Analysis: Crime by Locale

\begin{tabular}{lrrrr}
\hline & Urban & Suburban & Rural & Total \\
\hline \multicolumn{5}{c}{ Forgery and Counterfeiting } \\
Empirical & 37788 & 16188 & 7597 & 61573 \\
Expected & 34910 & 17141 & 9522 & \\
& \multicolumn{4}{c}{ Fraud } \\
Empirical & 89723 & 47453 & 38570 & 175746 \\
Expected & 99643 & 48925 & 27178 \\
& \multicolumn{5}{c}{ Embezzlement } \\
Empirical & 6150 & 1709 & 758 & 8617 \\
Expected & 4886 & 2399 & 1333 \\
& \multicolumn{5}{c}{ Stolen Property } \\
Empirical & 65126 & 32255 & 7295 & 104676 \\
Expected & 59348 & 29140 & 16188 \\
& \multicolumn{5}{c}{ Overall } \\
Total & 198787 & 97605 & 54220 & $350612^{*}$ \\
\hline
\end{tabular}

Note $-\chi^{2}(6)=13,037.458$.

*Slightly larger data base than in Tables 1-3. 
Table 5

Crime Data Analysis: Cost-Benefit Summary

\begin{tabular}{|c|c|c|c|c|c|c|}
\hline Crime & $\begin{array}{c}\text { Frequency } \\
\text { of Arrest }\end{array}$ & $\begin{array}{l}\text { Average Mone- } \\
\text { tary Value }\end{array}$ & $\begin{array}{l}\text { Number of } \\
\text { Defendants }\end{array}$ & $\begin{array}{c}\text { Number } \\
\text { Sentenced }\end{array}$ & $\begin{array}{l}\text { Average } \\
\text { Penalty }\end{array}$ & $\begin{array}{l}\text { Approxi- } \\
\text { mate Risk }\end{array}$ \\
\hline Forgery/Counterfeiting & 55791 & $1396 *$ & 4704 & 4115 & 32.7 & $1: 12$ \\
\hline Fraud & 161351 & 31000 & 5782 & 4809 & 19.9 & $1: 28$ \\
\hline Embezzlement & 8218 & 487000 & 2151 & 1921 & 17.3 & $1: 4$ \\
\hline Stolen Property & 92026 & 745 & 6184 & 5141 & 37.4 & $1: 15$ \\
\hline
\end{tabular}

Note-Average monetary value is given in dollars; average penalty is given in months.

${ }^{*}$ Confiscated plus passed on the public; amount passed on the public $=\$ 694$.

proportional to the average penalty in months of imprisonment for the respective crime category. Whereas the sentence for embezzlement is lenient, the potential benefit from such a crime is quite high. In contrast, stolen property realizes a low payoff and a relatively high penalty.

\section{DISCUSSION}

The analyses of the data on frequency of arrests for crimes of interpersonal deception compared with those of stolen property have revealed several findings that are compatible with the hypothesis that human deception is advantageous. Whereas there are several interesting differences among the categories of fraud, embezzlement, and forgery-counterfeiting, their costto-benefit indexes are all considerably less than that for stolen property. The salient points in this regard are as follows: (1) The frequency of arrests for fraud far exceeds that of stolen property; (2) whereas crimes of stolen property are primarily committed by the young, crimes of deception (particularly fraud) peak between 20 and 30 years of age but are also relatively frequent up to the age of 60 years; (3) fraud is prevalent in areas of both high (urban) and low (rural) population density, whereas, almost by definition, crimes of stolen property, embezzlement, and forgery-counterfeiting are restricted primarily to urban and suburban areas; (4) female offenders are relatively frequent in crimes of deception and far less prevalent than males in crimes of stolen property; (5) in cases of fraud, there is a low risk of indictment, minimal penalty, and a relatively high potential gain; (6) even though the risk of embezzlement is considerably higher, so are the potential gains, but in the case of stolen property, the likely benefit is far exceeded by the relatively high risk and greater punishment.

To summarize, what these data suggest is that fraud may be committed by both men and women throughout most of their adult lives, but particularly during their maximal reproductive years, in locations of relative obscurity such as large cities or with inexperienced targets such as in rural areas, at low risk, with relatively high return. Embezzlement and forgerycounterfeiting are ploys on a similar theme, but for which opportunity and experience are important factors. In terms of Wallace's (1973) model of human deception, all three categories of crime are usually perpetrated in anonymity and among strangers, in situations in which the likelihood of detection or the motivation for prosecution is relatively low.

So it would seem, as in social animals more generally, human deception may be adaptive if these cost-benefit indexes are indic- ative of a biological advantage as well as an economic one. It is relatively clear that crime in general does pay (e.g., Becker, 1968; Ehrlich, 1973) and that crimes of deception have a high monetary return at low risk. Nevertheless, the question still unanswered by the present data is whether money and babies (i.e., reproductive success) can be equated, although it is a reasonable hypothesis that they can. The resources available to parents, through purchase or inheritance, undoubtedly influence the number and/or health of their offspring or those of close relatives that do survive, in turn, to reproduce still more kin.

\section{REFERENCES}

Adle r, F. Sisters in crime. New York: McGraw-Hill, 1975. Assem, J., van DEN. Territory in the three-spined stickleback, Gasteroceus aculeatus. Behaviour Supplements, 1967, 16, 1-164. BeCKer, G. S. Crime and punishment: An economic approach. Journal of Political Economy, 1968, 76, 169-217.

Eнrlich, I. Participation in illegitimate activities: A theoretical and empirical investigation. Journal of Political Economy, 1973, 81, 521-565.

Hamilton, W. D. The genetical evolution of social behaviour. I. Journal of Theoretical Biology, 1964, 7, 1-16.

House of Representatives, 95Th Congress. White collar crime: The problem and the federal response (Report of the Committee on the Judiciary, Subcommittee on Crime). Washington, D.C: U.S. Government Printing Office, 1978.

Hrdy, S. B. The langurs of $\mathrm{Abu}$. Cambridge, Mass: Harvard University Press, 1977.

Kessell, E. L. Mating activities of balloon flies. Systematic Zoology, 1955, 4, 97.-104.

MAYNARD-Smith, J. Evolution and the theory of games. American Scientist, 1976, 64, 41-45.

OtTe, D. On the role of intraspecific deception. American Naturalist, 1975, 109, 239-242.

U.S. Department of Justice. Sourcebook of criminal justice statistics, 1978. Washington, D.C: U.S. Government Printing Office, 1978.

Wallace, B. Misinformation, fitness and selection. American Naturalist, 1973, 107, 1-7.

WEBSTER, W. H. (Ed.). Crime in the United States-FBI uniform crime reports. Washington, D.C: U.S. Government Printing Office, 1978.

(Received for publication June 30, 1980.) 